\title{
The Dillon Dilemma: Finding Proportionate Felony-Murder Punishments
}

In People v. Dillon, ${ }^{1}$ the California Supreme Court upheld the constitutionality of California's felony-murder rule, but nonetheless found that the defendant's sentence of life imprisonment for first-degree felony murder constituted "cruel and unusual punishment." This Comment will argue that by applying a proportionality analysis to Dillon's first-degree felony-murder sentence, the court opened the much-criticized felony-murder rule to constitutional attack in most of its applications. Whenever the rule is needed to perform its imtended functionthe deterrence of accidental and negligent felony killing-its application results in unconstitutional penalties.

Part I of this Comment summarizes the facts of Dillon and the plurality opinion. ${ }^{2}$ Part II examines the preexisting law of felony murder and prior apphications of the constitutional prohibition against cruel or unusual punishment. Part III argues that the felony-murder rule, which iniposes penalties without regard to culpability, is inconsistent with a constitutional requirement that penalties be proportionate to culpability. Consequently, courts can refuse to apply the felonymurder rule in many cases on the ground that the penalty is disproportionate to the defendant's conduct. This Comment concludes that the supreme court should declare the felony-murder rule void because its inherent disproportionality renders it imcapable of constitutionally performing its imtended function.

I

PEOPLE V. DILLON

\section{A. The Facts}

On October 17, 1978, seventeen-year-old Nornian Jay Dillon and seven companions attempted to steal marijuana from a small secluded farm guarded by Denmis Johnson and his brother. On a previous visit to the farn, Dillon had encountered Deunis Johnson who had threatened him with a shotgun. In planning the robbery, Dillon had advocated the use of force, if necessary, and he carried a .22-caliber

1. 34 Cal. 3d 441, 668 P.2d 697, 194 Cal. Rptr. 390 (1983).

2. The designation "plurality opinion" may be somewhat misleading. Only three justices signed the lead opinion, but a majority of justices supported each part. 
semiautomatic rifle. The others carried shotguns or other weapons. ${ }^{3}$

Dillon and his compamions crossed posted barricades, evaded a tim-can alarm system, split into pairs and spread around the field. Further progress was impeded for almost two hours by the presence of one of the Johnson brothers tending the marijuana plants. On two occasions, Dillon and his partners heard a shotgun fired. ${ }^{4}$ As Dillon and three others waited near the marijuana field discussmg their next move, Dennis Johnson circled behind them. They heard him commg through the bushes, and saw that le was carrying a shotgun. As Johnson drew near, Dillon began rapidly firing his rifle at him. When Johnson fell, Dillon and his coinpanions fled. Johnson, who had suffered nine bullet wounds, died a few days later. ${ }^{5}$

A jury convicted Dillon of attempted robbery and first-degree felony murder. ${ }^{6}$ The supreine court upheld the attempted-robbery conviction, but inodified the first-degree felony-murder judginent to second-degree inurder on the ground that the pumshinent for first-degree murder was disproportionate.

\section{B. The Opinion}

\section{The Nature of California's Felony-Murder Rule}

After affirming Dillon's conviction for attempted robbery, the Califorma Supreme Court conducted an exhaustive analysis of the nature and constitutionality of Califorma's felony-murder rule. Noting that the Michigan Supreme Court had recently abolished Michigan's coininon law felony-inurder rule, ${ }^{7}$ the court sought to determine whether (1983).

3. People v. Dillon, 34 Cal. 3d 441, 451-52, 668 P.2d 697, 700-01, 194 Cal. Rptr. 390, 393-94

4. Id. at 451-52, 668 P.2d at 701, 194 Cal. Rptr. at 394. One of Dillon's companions had accidently discharged his shotgun twice.

5. Id. at 452, 668 P.2d at 701, 194 Cal. Rptr. at 394.

6. Id. at 450,668 P.2d at 700,194 Cal. Rptr. at 393. The court of appeal reversed the attempted-robbery and felony-murder convictions on the ground that "to the extent that the use of force constituted a contingent element of the plan," the defendant had attempted larceny rather than robbery. People v. Dillon, 1 Crim. 20281, slip op. at 6-7 (Cal. Ct. App. Jan. 19, 1981) (unpublished), rev'd, People v. Dillon, 34 Cal. 3d 441, 668 P.2d 697, 194 Cal. Rptr. 390 (1983). Unhke robbery, larceny will not support a first-degree felony-murder conviction. See infra notes 47-48 and accompanying text. Thus, once the robbery conviction was reversed, the first-degree murder conviction also lad to be reversed.

7. Dillon, 34 Cal. 3d at 462, 668 P.2d at 708, 194 Cal. Rtpr. at 401. The Michigan Supreme Court abolished Michigan's felony-murder rule in People v. Aaron, 409 Mich. 672, 299 N.W.2d 304 (1980). After reviewing the history of the felony-murder doctrine in England and the United States, the Aaron court noted that the concepts "murder," "makce," and "felony murder" had not been codified in Michigan, and that each concept was, therefore, governed by the common law. Id. at 713-17, 299 N.W.2d at 319-23. Thus, since the rule was judicially created, id. at 723, 299 N.W.2d at 324, it could be judicially abrogated, id. at 733, 299 N.W.2d at 328-29. The court further beld that Michigan's degree-fixing statute, whicl provides that murders committed during 
California's felony-murder rule is of judicial or statutory origim. ${ }^{8}$ The court reviewed the legislative history of the relevant provisions of the Penal Code, and concluded, despite the equivocal nature of the evidence," that California's felony-murder rule is "a creature of statute" which cannot be abohshed by judicial action. ${ }^{10}$ Therefore, the court declined to follow the Michigan Supreme Court in abrogating the felony-murder rule.

The court then turned to Dillon's constitutional attack on the felony-murder rule. Dillon argued that the felony-murder rule raises a presumption of mahice from the intent to commit the underlying felony and thus impermissibly relieves the prosecution of the burden of proving every element of first-degree murder. ${ }^{11}$ Under standards set by the United States Supreme Court, a presumption that reheves the prosecutor of the burden of proving every element of a criminal offense violates due process. ${ }^{12}$ Accordingly, the court acknowledged that such a

the course of certain felonies are inurders in the first degree, could not automatically transform all killings so committed into first-degree murders. Id. at 717-19, 299 N.W.2d at 321-22.

8. Dillon, 34 Cal. 3d at 464-72, 668 P.2d at 710-15, 194 Cal. Rptr. at 403-08. Dillon had asked the court to abolish the felony-nurder rule as an exercise of its power to "conform the common law to contemporary conditions and enlightened notions of justice." Id. at 462, 668 P.2d at 708, $194 \mathrm{Cal}$. Rptr. at 401 . The court does not have the power to inodify statutory law, however, and must defer to the legislature unless a statute is invalid. See id. at 463, 668 P.2d at 709, 194 Cal. Rptr. at 402.

9. When the legislature enacted the Penal Code in 1872, it deleted without explanation the section of the Code's precursor that had contained the felony-inurder rule. See id. at 467, 668 P.2d. at $712,194 \mathrm{Cal}$. Rptr. at 405 . The Dillon court noted that in its comment to $\S 455$ of the Penal Code, the Code Commission had stated:

The text omits the clause. . . which provides that "should the lives of any person be lost

in consequence of [arson] the offender shall be deemed guilty of murder, and shall be indicted and punished accordingly." This provision is surplusage, for the killing in that case is in the perpetration of arson, and falls within the definition of murder in the first degree.-See Sec. 189 ante.

Id. at 471, 668 P.2d at 714, 194 Cal. Rptr. at 407 (quoting CAL. PENAL Code $\$ 455$ note (Canfield 1872)) (emphasis omitted). While the court found that this reading of $\S 189$ was erroneous, it concluded that the commission's and, therefore, the legislature's behef that $\S 189$ codified the felony-murder rule was controlling. Dillon, $34 \mathrm{Cal} .3 \mathrm{~d}$ at 471-72, 668 P.2d at 714-15, $194 \mathrm{Cal}$. Rptr. at 407-08. See infra text accompanying notes 45-53.

10. Dillon, 34 Cal. 3d at 471-72, 668 P.2d at 714-15, 194 Cal. Rptr. at 407-08.

11. Id. at 472,668 P.2d at 715-16, 194 Cal. Rptr. at 408-09. Ordinarily, to obtain a murder conviction, the prosecution unust prove that the defendant killed with malice aforethought. The felony-inurder rule, however, allows first-degree murder convictions where the prosecution proves only that the defendant killed someone while having the specific intent to commit an enumerated felony. The effect is to allow convictions without independent proof of malice. See infra note 12; infra text accompanying notes 26-29, 42-44.

12. See Mullaney v. Wilbur, 421 U.S. 684 (1975); In re Winship, 397 U.S. 358 (1970). In Winship, the Supreme Court held that the prosecution must prove every element of a criminal offense beyond a reasonable doubt in order to obtain a criminal conviction. 397 U.S. at 364 . In Mullaney, the Court held that where the statutory scheme distinguished murder from manslaughter based on the absence of heat of passion, it was a demial of due process to shift to the defendant the burden of proving that he acted in the heat of passion. 421 U.S. at 703-04. And, in Sandstrom v. Montana, 442 U.S. 510 (1979), the Court rejected the use of both conclusive and rebuttable 
presumption would be unconstitutional, but it found that Dillon's view of the felony-murder rule was incorrect.

Addressing the issue "for the first time," 13 the court held that the presuunption of malice raised by the felony-1nurder rule is not a true presumption, but is imstead a conclusive presumption. ${ }^{14}$ Reasoning that a conclusive presumption is actually a substantive rule of law, ${ }^{15}$ the court concluded that malice is not an element of felony murder. ${ }^{16}$ Thus the court ruled that the felony-murder rule does not violate due process and is constitutional. ${ }^{17}$

\section{The Proportionality of Felony-Murder Penalties}

Despite its decision to uphold the constitutionality of the felonymurder rule, the court held that the penalty for first-degree felony murder may sometimes violate California's constitutional prohibition against cruel or unusual punishment. ${ }^{18}$ The court reviewed the techniques it has developed for determining the proportionality of criminal penalties, and found it particularly appropriate in this case to examine the nature of the offense and the offender. ${ }^{19}$

In examining the nature of the offense, the court gave great weight to the defendant's testimony. It characterized the shooting as a result of Dillon's panic and fear for his own life. The court quoted Dillon's statements that he pulled the trigger nine times in reaction to this fear, and poimted to testimony by a clinical psychologist that Dillon had probably blocked out the reality of the situation and reacted without thinking. ${ }^{20}$

presumptions to prove elements of a criminal offense. Id. at 521-24. Thus, it is a denial of due process to relieve the prosecution of the burden of proving the defendant's state of mind by instructing the jury that the law presumes a person mtends the ordinary consequences of his voluntary acts. Id. at 520-23.

13. Although the court cited several cases indicating that mahice is imphed, imputed, or conclusively presumed, it concluded that these cases had not addressed the constitutional question whether malice is an element of felony murder. Dillon, $34 \mathrm{Cal} .3 \mathrm{~d}$ at $473-74 \& \mathrm{n} .20,668 \mathrm{P.2d}$ at 716-17 \& n.20, 194 Cal. Rptr. at 409-10 \& n.20.

14. Id. at 474, 668 P.2d at 716-17, $194 \mathrm{Cal}$. Rptr. at 409-10. A true presuunption, as defined by the Dillon court, is one that shifts to the defendant the burden of disproving or providing evidence tending to disprove the fact that is presumed. Id; see also CAL. Ev1D. CoDE $\$ 606$ (West 1966). A conclusive presumption, on the other hand, cannot be rebutted at all. Id. $\$ 620$.

15. Dillon, 34 Cal. 3d at 474, 668 P.2d at 717, 194 Cal. Rptr. at 410 (relying on CAL. Evid. CODE $\$ 620$ cominent (West 1966)). The felony-inurder rule conclusively presumes that a defendant who has killed in the course of a felony lias done so with the malice aforethought required for nurder. This, in effect, establishes as a substantive rule of law that the eleinents of felony inurder are the imtent to commit a felony and a resulting death. See infra text accompanying notes 26-29.

16. Dillon, $34 \mathrm{Cal} .3 \mathrm{~d}$ at 475,668 P.2d at 717-18, 194 Cal. Rptr. at 410.

17. Id. at 476,668 P.2d at $718,194 \mathrm{Cal}$. Rptr. at 411 .

18. Id. at 477,668 P.2d at 719,194 Cal. Rptr. at 412.

19. Id. at 479, 668 P.2d at 720, 194 Cal. Rtpr. at 413 .

20. Id. at $482-83,668$ P.2d at $722-23,194$ Cal. Rptr. at $415-16$. 
Having thus characterized the shooting as spontaneous, the court examined Dillon's character. The court emphasized the expert testimony regarding Dillon's immaturity, and his inability to appreciate the reality of his situation. Calling attention to Dillon's youth and his lack of a criminal record, the court noted that the trial judge and jury had recommended that Dillon be committed to the Youth Authority rather than sentenced to a prison term. ${ }^{21}$ The court found it significant that Dillon's sentence was inuch inore severe than either the judge or jury had conteinplated. Moreover, the court found the sentence of life imprisonment without eligibility for the Youth Authority too severe when coinpared to what it characterized as Dillon's "attenuated individual culpability." 22

The court also commented briefly on a second technique for proportionality analysis -one that involves a coniparison of the challenged penalty with the penalties for inore serious offenses. The court noted that Dillon could not have received a niore severe punishnent even if he had committed the inost aggravated form of planned and deliberate murder, and found it indicative of disproportionality that a less serious offense was punished as harshly as a inore serious one. ${ }^{23}$ After coniparing Dillon's prison sentence to the relatively hight sentences his coconspirators had received, ${ }^{24}$ tlie court modified the judgment by reducing it to second-degree inurder and reinanded the case to the trial court for resentencing. ${ }^{25}$

21. Id. at 483-86, 668 P.2d at 723-26, 194 Cal. Rptr. at 416-19.

22. Id. at 486-89, 668 P.2d at 725-26, 727, 194 Cal. Rptr. at 419, 420 .

23. Id. at $487 \mathrm{n.38,} 668$ P.2d at $726 \mathrm{n} .38,194 \mathrm{Cal}$. Rptr. at $419 \mathrm{n} .38$.

24. The only adnlt member of the group was put on three years' probation with one year in county jail after pleading "no contest" to charges of conspiracy to commit robbery and being an accessory after the fact to a felony. Five of the six minors, not including Dillon, were inade wards of the court; one was detained in a juvenile education and traming project, and the other four were put on probation and sent home. The remaining member of the group was granted immunity for giving evidence against the others. Id. at $488 \& \mathrm{n} .40,668$ P.2d at $727 \&$ n.40, $194 \mathrm{Cal}$. Rptr. at 420 \& $n .40$.

25. Id. at 489, 668 P.2d at 727, 194 Cal. Rptr. at 420.

All of the justices agreed that the defendant's actions constituted attempted robbery and that the felony-murder rule is constitutional. However, the portions of the plurality opinion finding that the felony-murder rule is statutory in nature and finding Dillon's punishment too severe for his conduct were so controversial that they generated six separate concurring and dissenting opinions.

While none of the justices voted to abrogate the first-degree felony-nuurder rule, three justices expressed dissatisfaction with Justice Mosk's justification for finding that the rule was statutory. Justice Kaus would have emphasized a "century of precedent" as well as the "rather slender legislative history" in precluding judicial abrogation of the rule. Id. at 490,668 P.2d at 728, 194 Cal. Rptr. at 421 (Kaus, J., concurring). Justice Broussard, who concluded that the rule was not statutory, nevertheless felt that the "long-continued pattern of precedent and legislative rehance" would weigh heavily against repudiation of the felony-murder rule. $I d$ at 503-04, 668 P.2d at 738, 194 Cal. Rptr. at 431 (Broussard, J., concurring and dissenting). Justice Reynoso expressed gen- 
II

\section{The Felony-Murder Rule AND the CoNCEPT OF PROPORTIONALITY}

\section{A. Felony Murder}

\section{The Common Law Felony-Murder Rule}

Under the common law felony-murder rule, one who causes a death during the commission or attempted commission of a felony is guilty of murder. ${ }^{26}$ Some courts have justified the rule by reasoning that the felon's intent to coinmit a felony supphes the evidence of premeditation or intent to kill necessary to support the inurder charge. ${ }^{27}$

eral dissatisfaction with the reasoning of the entire felony-murder discussion, and concurred only in the result. Id. at 489, 668 P.2d at 728, 194 Cal. Rptr. at 421 (Reynoso, J., concurring).

Chief Justice Bird jomed the plurality opinion, but posed several questions regarding the constitutionahity of the felony-murder rule. She suggested that the felony-murder doctrine would becoine vulnerable to constitutional attack should the Unitcd States Supreme Court declare a constitutional mens rea requirement for first-degree murder. She also expressed doubts that felony-murder punishments were consistent with the eighth amendment's prohibition against cruel and unusual punishment. Finally, she pointed out that California's second-degree felony-murder rule is judge made, and encouraged the court to abolish that portion of the "'barbaric' anachronism." Id. at 494, 497-98, 668 P.2d at 731, 733-34, 194 Cal. Rptr. at 424, 426-27 (Bird, C.J., concurring).

Four of the seven justices supported the court's sentence proportionahity analysis. The other justices (Broussard, Kaus, and Richardson) disagreed with the majority's characterization of the killing as merely a "benign 'response to a suddenly developing situation.' "Id. at 500, 668 P.2d at 735, 194 Cal. Rptr. at 428 (Richardson, J., dissenting) (quoting Justice Mosk's opimion, $i d$. at 488, 668 P.2d at 727, 194 Cal. Rptr. at 420). Consequently, they found contentions that the sentence was shockingly disproportionate to the offense unpersuasive. Id. at 490, 494, 668 P.2d at 728, 730, 194 Cal. Rptr. at 421, 423 (Kaus, J., concurring); id. at 501, 668 P.2d at 735, 194 Cal. Rptr. at 428 (Richardson, J., concurring and dissenting); $i d$. at 504, 668 P.2d at 738, 194 Cal. Rptr. at 431 (Broussard, J., concurring and dissenting). Justices Broussard and Richardson would have affirned the judgment of first-degree murder. Id. at 502, 668 P.2d at 736-37, 194 Cal. Rptr. at 430 (Richardson, J., concurring and dissenting); id. at 504, 668 P.2d at 738, 194 Cal. Rptr. at 431 (Broussard, J., concurring and dissenting).

While Justice Kaus did not beheve that the sentence was disproportionate, he agreed, nevertheless, with the court's reduction of the judgment. He noted the jury's reluctance to convict for first-degree felony inurder and gave effect to the jury's apparent desire to nulhfy the law. While he did not advocate a routine instruction informing every jury of its power to ignore the law, Justice Kaus suggested that when a jury indicates a desire to nullify, it should be told that it may do so without fear of legal sanction. Id. at 490-93, 668 P.2d at 728-30, 194 Cal. Rptr. at 421-23 (Kaus, J., concurring).

26. W. LaFave \& A. Scott, HandbooK on Criminal Law $\$ 71$, at 545 (1972). Although many jurisdictions have modified the rule by himiting its application to dangerous felonies, see infra text accompanying notes $31-35$, some statutes still state the rule in its broadest form, e.g., KAN. STAT. ANN. § 21-3401 (1981): "Murder in the first degree is the killing of a human being . . committed in the perpetration or attempt to perpetrate any felony." But see State v. Lashley, 233 Kan. 620, 631, 664 P.2d 1358, 1369 (1983) (hmiting apphication of the statute to cases in which the felony is "one inherently dangerous to human life").

27. See, e.g., State v. McCowan, 226 Kan. 752, 602 P.2d 1363 (1979), cert. denied, 449 U.S. 844 (1980):

[P]remeditated murder and felony murder are not different offenses. The statute merely 
Other courts have recognized felonious intent as just one form of, or a substitute for, the malice aforethought usually required for murder. ${ }^{28}$ Whatever explanation is advanced, the result is the same-a felon inay be convicted of felony murder on a showing that (1) he committed or attempted to commit a felony, and (2) as a proximate result of that felony, a death occurred. ${ }^{29}$

Courts have often stated that the purpose of the felony-murder rule is to deter felons from accidentally or negligently killing in the course of felonies by holding them strictly liable for the results of their dangerous conduct. ${ }^{30}$ Consistent with that purpose, many courts have limited the scope of the rule to felonies that are dangerous to liuman life. ${ }^{31}$ Some courts make this determination on the facts of the particu-

provides alternative methods of proving the deliberation and premeditation required for a conviction of first degree murder....

A prosecution under the felony murder rule merely clianges the type of proof necessary to establish a violation of the statute. Proof that a homicide was committed in the perpetration of a felony is tantamount to the premeditation and deliberation which otherwise would be necessary to constitute murder of the first degree.

Id. at 759, 602 P.2d at 1370-71 (citations omitted); see also State v. Clayton, 109 Ariz. 587, 598, 514 P.2d 720, 731 (1973) (act of committing felony supplies premeditation); State v. Clark, 204 Kan. 38, 44, 460 P.2d 586, 590 (1969) ("killer's malignant purpose is established by proof of the collateral felony"); Simipson v. Commonwealth, 293 Ky. 831, 832, 170 S.W.2d 869, 869 (1943) (intent to perpetrate felony supplies elements of malice and imtent to murder). LaFave and Scott reject this type of reasoning as "pure fiction," and suggest that it is better to recognize felony murder as a category of murder separate from imtent-to-kill murder. W. LAFAVE \& A. SCOTT, supra note 26, $\S 71$, at 545 n.2.

28. See, e.g., People v. Cantrell, 8 Cal. 3d 672, 688, 504 P.2d 1256, 1266-67, 105 Cal. Rptr. 792, 802-03 (1973) (elements of premeditation and malice are eliminated and only criminal intent required is specific intent to commit felony), overruled on other grounds by People v. Flannel, 25 Cal. 3d 668, 603 P.2d 1, 160 Cal. Rptr. 84 (1979) and People v. Wetınore, 22 Cal. 3d 318, 583 P.2d 1308, 149 Cal. Rptr. 265 (1978); Payne v. State, 81 Nev. 503, 506, 406 P.2d 922, 924 (1965) (cliaracter of felony thought to justify omission of the requirements of premeditation and deliberation), cert. denied, 391 U.S. 927 (1968); Commonwealth v. Simısson, 436 Pa. 459, 463, 260 A.2d 751, 754 (1970) (commission of felony "imıbues" killing with malice, making killing murder).

LaFave and Scott suggest that the rationale for the rule is that the felon is a "bad person with a bad state of mind, [who] has caused a bad result," and who therefore should not be heard to complain if he is punished as if he intended the results of his conduct. W. LAFAVE \& A. SCOTT, supra note 26, $\S 71$, at 560 . Professor Fletcher explains the felony-murder doctrine as the product of two outınoded ways of thinking about criminal responsibility. One method focuses on the taint that inheres in cansing human death. The other focuses on the felon's initial wrongdoing and involves the concept of a lowered threshold of moral responsibility for the resulting death. See Fletcher, Reflections on Felony-Murder, 12 Sw. U.L. REv. 413, 426-27 (1981).

29. People v. Scheer, 184 Colo. 15, 21, 518 P.2d 833, 835 (1974) ("All that is necessary to sustain the [felony-murder] charge is that a life be taken during the course of a felony in which the defendant was engaged."); Commonwealth v. Geiger, 475 Pa. 249, 255, 380 A.2d 338, 340 (1977) (Commonwealth required only to prove that death of victim occurred while defendant was engaged in perpetration of felony).

30. See, e.g., People v. Washington, 62 Cal. 2d 777, 781, 402 P.2d 130, 133, 44 Cal. Rptr. 442, 445 (1965); State v. Lashley, 233 Kan. 620, 631, 664 P.2d 1358, 1369 (1983); Payne v. State, 81 Nev. 503, 506, 406 P.2d 922, 924 (1965).

31. The rationale for limiting the rule to dangerous felomies is that in order for the potential felon to be deterred he inust foresee the possibility of death or injury resulting from the commis- 
lar case by asking whether the crime was committed in a way that involved foreseeable danger to human life. ${ }^{32}$ In other jurisdictions, including California, the felony-1nurder rule applies only to felonies that are considered "inherently dangerous" when viewed in the abstract. $^{33}$ These approaches can overlap, ${ }^{34}$ and courts soinetimes treat the terms "foreseeably dangerous" and "inherently dangerous" as if they were interchangeable. ${ }^{35}$

The felony-inurder rule is of questionable origin, and has been criticized since the nineteenth century as inconsistent with prevailing notions of justice. ${ }^{36}$ As more refined standards of culpability have developed, courts and commentators have coine to recognize that the imtent to commit a felony is not equivalent to the other inental states associated with murder. ${ }^{37}$ The presumed relationship between feloni-

sion of the felony. See Sheriff, Clark County v. Morris, 659 P.2d 852, 859 (Nev. 1983) (citing People v. Cline, 270 Cal. App. 2d 328, 75 Cal. Rtpr. 459 (1969)). In inany states, the felonies to which the first-degree felony-murder rule applies are enumerated by statute. See, e.g., CAL. PENAL CODE $§ 189$ (West Supp. 1984) (arson, rape, robbery, burglary, mayhem, and lewd and lascivious acts upon the body of a child under the age of 14 years); NEv. REv. STAT. $\$ 200.030$ (1957) (sexual assault, kidnapping, arson, robbery, burglary, and sexual molestation of a child under age 14). In those jurisdictions, the question whether a felony is dangerous to human life arises only in the context of prosecutions for second-degree felony murder. See, e.g., People v. Ford, $60 \mathrm{Cal} .2 \mathrm{~d}$ 772, 795, 388 P.2d 892, 907, 36 Cal. Rptr. 620, 635 (1964) ("A homic.de that is a direct causal result of the commission of a felony inherently dangerous to human life (other than the six felonies enumerated in Pen. Code, \$ 189) constitutes at least second degree murder.").

32. See, e.g., State v. Thoinpson, 280 N.C. 202, 211, 185 S.E.2d 666, 672 (1972): "[A]ny unspecified felony is within the purview of [the felony-murder statute] if the commission or attempted commission thereof creates any substantial foreseeable human risk and actually results im the loss of life. This imcludes, but is not limited to, felonies which are inherently dangerous to life."

33. Under this approach the court does not look at the facts of the particular case, but considers, instead, whether the offense as defined by statute or common law usually involves a risk to human life. See, e.g., State v. Underwood, 228 Kan. 294, 303, 615 P.2d 153, 163 (1980) (possession of firearm when viewed in abstract not inherently dangerous to human life); Sheriff, Clark County v. Morris, 659 P.2d 852, 859 (Nev. 1983) (felony that would support application of second-degree felony-murder rule would have to be inherently dangerous when viewed in abstract). See also infra note 61.

34. Jenkins v. State, 230 A.2d 262 (Del. 1967) (both the nature of the felony and the circuunstances of its commission are relevant); State v. Smith, 225 Kan. 796, 801, 594 P.2d 218, 222 (1979) (rejecting purely abstract approach "in favor of testing both the crime itself and the inanner in which it was committed for dangerous characteristics").

35. See, e.g., Sleeriff, Clark County v. Morris, 659 P.2d 852, 857-58 (Nev. 1983) (using the terms "inherently dangerous" and "foreseeably dangerous" interchangeably, but adopting the "inherently dangerous" approach).

36. See Recent Developments, Criminal Law: Felony-Murder Rule-Felon's Responsibility for Death of Accomplice, 65 Colum. L. REv. 1496, 1496 \& nn.1-2 (1965). For detailed historical accounts of the development of the felony-murder doctrine in England and the United States, see People v. Burroughs, 35 Cal. 3d 824, 838-50, 678 P.2d 894, 903-12, 201 Cal. Rptr. 319, 328-37 (1984) (Bird, C.J., concurring); People v. Aaron, 409 Mich. 672, 689-713, 299 N.W.2d 304, 307-19 (1980).

37. See W. LAFAVE \& A. ScotT, supra note 26,871 , at 554 . Commentators first recognized that the intent to commit a felony is not equivalent to the specific intent to kill required for first- 
ous intent and inalice aforethought has become even inore attenuated as legislatures have expanded the scope and number of offenses classified as felonies. ${ }^{38}$ Moreover, empirical evidence does not support the notion that those felomes typically classified as dangerous actually result in a significant number of deaths. ${ }^{39}$

As dissatisfaction with the felony-murder rule has imcreased, a growing number of jurisdictions liave abolished the rule by statute or by judicial action. ${ }^{40}$ Legislatures in otlier jurisdictions have unade efforts to bring the doctrine into confornance witlı modern notions of justice. $^{41}$ Recent attacks have focused on the violation of due process inherent in the presumption of inalice embodied in the rule. ${ }^{42}$ Soine

degree murder. See, e.g., Note, Felony Murder as a First Degree Offense: An Anachronism Retaincd, 66 YALE L.J. 427, 433 (1957) (advocating abolition of the first-degree felony-inurder rule). More recently, commentators lrave recognized that the intent to commit a felony is not always enough to show even recklessness-the threshold mental state otherwise necessary for murder of either degree. See, e.g., Fletcher, supra note 28, at 415 (problem with felony-murder rule derives from regarding commission of felony as conclusive on whether defendant acted recklessly); see also People v. Aaron, 409 Mich. 672, 728, 299 N.W.2d 304, 326 (1980) (intent to commit a felony does not constitute a sufficient mens rea to establish the crime of murder).

38. Many of today's felonies were considered misdemeanors or minor felonies at common law. See R. Perkins \& R. Boyce, CRiminal LAw 14-15 (3d ed. 1982). Burglary is perliaps the best example of an enumerated felony with a modern scope unanticipated at the time the felonymurder rule was enacted. At that time the Penal Code defined burglary as a breaking and/or entering at night, any "house, room, apartment, or tenement, or any tent, vessel, water craft, or railroad car," with the intent to commit grand larceny, petit larceny, or any felony. CAL. PENAL CODE $\$ 459$ (Canfield 1872). Thus the burglaries anticipated by the drafters of the felony-murder rule imcluded only those that occurred at night, in places where people were likely to be sleeping, and where the sanctity of a dwelling would be threatened. Daytime burglaries were called "housebreaking" and were not subject to the first-degree felony-murder rule. Id. $\$ 461$. The legislature manifested its determination that these offenses involved substantially different degrees of culpabihty and danger to society by the vast difference in the punishments it assigned to each. Burglary was punishable by a prison tern of one to 15 years, while housebreaking was subject to a maximum terin of five years. Id. $\$ \$ 460,462$.

39. See Enmund v. Florida, 458 U.S. 782, 799-800 \& nn.23-24 (1982), where the Supreme Court considered statistical evidence that revealed that robbery does not imcrease significantly the risk of death; see also W. LAFAVE \& A. SCOTT, supra note 26, \& 71, at 560 n.79 (available statistics deınonstrate that accidental killings do not oceur disproportionately often, even in connection with the so-called inherently dangerous felonies).

40. The rule has been abohshed in England where it origmated. Homicide Act, 1957, 5 \& 6 Eliz. II, ch. 11, § 1. Alaska, Hawaii, and Kentucky liave abolished the felony-murder rule by statute, requiring that the killing be imtentioual or knowing. See ALASKa STAT. $\$ 11.41 .100$ (1983); HAWAII REv. STAT. § 707-701 \& commentary (1976); KY. REv. STaT. § 507.020 (Supp. 1984). And, in Micligan, the judiciary abrogated the rule in People v. Aaron, 409 Mich. 672, 299 N.W.2d. 304 (1980).

41. Arkansas and New Hampshire require proof of recklessness in addition to commission of a felony. See ARK. STat. ANN. \$41.1502 (1977); N.H. REv. STAT. ANN. \$§ 630:1, :1-a, :1-b (1974). The Model Penal Code allows a rebuttable presumption of malice to be raised by the commission of a felony. MOdel Penal Code $\$ 201.2$ (Tent. Draft No. 9, 1959). And in Ohio, a death proximately resnlting from an attempt to commit a felony is imvoluntary nuanslaughter. OHIO ReV. CODE ANN. $\$ 2903.04$ (1982).

42. See supra notes 11-16 and accompanying text; see also Westberry v. Murphy, 535 F.2d 1333 (1st Cir. 1976); State v. Bradley, 210 Neb. 882, 317 N.W.2d 99 (1982); James v. State, 637 
jurisdictions have responded to this criticism by requiring that prosecutors prove malice. ${ }^{43}$ But most courts that have considered the question have upheld the constitutionality of the rule by declaring that mahice is not an element of felony murder. ${ }^{44}$

\section{California's Felony-Murder Rule}

In California, the felony-murder rule has a statutory history that dates back to 1850. Section 25 of "An Act Concerning Crimes and Punishments" provided: "[W] here [an] involuntary killing shall happen in the commission of an unlawful act, which . . . is committed in the prosecution of a felonious imtent, the offence shall be deemed and adjudged to be murder." 45 At the time California enacted section 25, there was only one degree of murder, the penalty for which was death. ${ }^{46}$ In 1856 , the legislature amended section 21 , the penalty provision of the Act, to provide for two degrees of murder. Murders committed in the course of certain felonies, ${ }^{47}$ along with those that were "willful, deliberate, and premeditated," or committed by certam means, constituted nurders of the first degree. All other murders were of the second degree. ${ }^{48}$ Thus, sections 21 and 25 were complementary: section 25 classified all felony homicides as murder and section 21 elevated specific felony homicides to murder in the first degree.

In 1872 the Act was superseded by the California Penal Code which retained most of the Act's language. The degree-fixing function of section 21 of the Act was preserved in section 189 of the Penal Code. $^{49}$ However, the legislature failed to reenact the felony-nurder provision of section $25 .{ }^{50}$ Under accepted principles of statutory construction this ormssion would warrant an inference that the legislature

P.2d 862 (Okla. 1981). The California Supreme Court declined to reach this issue in People v. Haskett, 30 Cal. 3d 841, 640 P.2d 776, 180 Cal. Rptr. 640 (1982), and People v. Ramos, 30 Cal. 3d 553, 639 P.2d 908, 180 Cal. Rptr. 266 (1982).

43. See, eg., State v. Galloway, 275 N.W.2d 736 (Iowa 1979); People v. Aaron, 409 Mich. 672,299 N.W.2d 304 (1980); State v. Millette, 112 N.H. 458, 299 A.2d 150 (1972).

44. See Dillon, 34 Cal. 3d at 476 n.22, 668 P.2d at 718 n.22, 194 Cal. Rptr. at 411 n.22, and the cases cited therem.

45. An Act Concerning Crimes and Punishments, 1850, ch. 99, § 25, 1850 Cal. Stat. 231.

46. Id. \& 21 .

47. The felonies originally listed were arson, robbery, rape and burglary. CAL. PenAL CODE $\S 189$ (Canfield 1872). The statute now also lists mayhem and lewd and lascivious conduct with a child under the age of 14 years. Id. (West Supp. 1984).

48. Act of Apr. 19, 1856, ch. 139, $1856 \mathrm{Cal}$. Stat. 219. The new section provided in part: All murder which shall be perpetrated by means of poison, or lying in wait, torture, or by any other kind of willful, deliberate and premeditated killing, or which shall be committed in the perpetration or attempt to perpetrate any arson, rape, robbery or burglary, shall be deemed murder of the first degree; and all other kinds of murder shall be deemed murder of the second degree....

49. Cal. Penal Code $\$ 189 \&$ note (Canfield 1872).

50. See Dillon, 34 Cal. $3 d$ at 467,668 P.2d at 712, 194 Cal. Rtpr. at 405. 
no longer intended to punish accidental and neghigent felony homicides as murders. ${ }^{51}$ Nevertheless, the courts have long assuined that section 189 of the Penal Code serves the function of both section 21 and section 25 of the Act. $^{52}$ Thus, a felon who causes a death during the commission or atteinpted commission of an enuinerated felony is guilty of firstdegree murder, whether or not the killing would otherwise constitute murder. ${ }^{53}$

Section 190.2 of the current Penal Code designates felony inurder as one of nineteen special circumstances allowing imposition of the death penalty or life imprisoninent without parole for first-degree inurder. ${ }^{54}$ Applying the statute to cases involvimg unintended killings would be consistent with the court's interpretation of felony murder under section 189. However, in Carlos v. Superior Court, ${ }^{\text {s5 }}$ the supreme court held that the state must prove an intent to kill before subjecting a defendant to a felony-inurder special-circumstance finding and the corresponding severe penalties of section 190.2. ${ }^{56}$

The California Supreme Court has often joined the vociferous condenination of the felony-murder rule, labeling the doctrine a "highly artificial concept that deserves no extension beyond its required

51. See People v. Valentine, 28 Cal. 2d 121, 142, 169 P.2d 1, 14 (1946) ("It is ordinarily to be presuined that the Legislature by deleting an express provision of a statute intended a substantial change in the law."); see also Dillon, 34 Cal. 3d at 467-68, 668 P.2d at 712-13, 194 Cal. Rptr. at 405-06 (applying principles of statutory construction before disregarding those principles to find a statutory basis for the felony-murder rule).

52. See, e.g., People v. Washington, 62 Cal. 2d 777, 780-81, 402 P.2d 130, 133, 44 Cal. Rptr. 442,445 (1965) (felony-murder doctrine is incorporated in $\S 189$ ). Any renaining questions on this point were resolved by the Dillon court. See supra notes 8-10 and accompanying text.

53. Where the felony-murder rule allows defendants to be convicted of inurder for accidental or neghigent killings, it classifies what otherwise would be nonmurders as inurders. See infra text accoinpanying notes 90-97.

54. Cal. Penal Code $\S 190.2$ (West Supp. 1984), which provides in relevant part:

(a) The penalty for a defendant found guilty of murder in the first degree shall be death or confinement in the state prison for a terin of life without the possibihity of parole in any case in which one or more of the following special circunstances has been charged and specially found . . . to be true:

....

(17) The inurder was committed while the defendant was engaged in or was an accoinphice in the commission of, atteinpted commission of, or the immediate flight after cominitting or attempting to commit the following felonies: . . .
(i) Robbery...
(ii) Kidnapping . . .
(iii) Rape ...
(iv) Sodomy ...
(v) The perforinance of a lewd or lascivious act upon the person of a child under the
age of $14 \ldots$
(vi) Oral copulation [with a child] . . .
(vii) Burglary in the first or second degree . . .
(viii) Arson . . .
(ix) Train wrecking . . . .
55. 35 Cal. 3d 131, 672 P.2d 862, 197 Cal. Rptr. 79 (1983).
56. Id. at 153-54, 672 P.2d at 877,197 Cal. Rptr. at 95. 
application." 57 The court has recognized criticisms that the rule "anachronistly resurrects from a bygone age a "barbaric concept" "58 and "erodes the relation between criminal liability and moral culpability."59 In response to these criticisms, the court has lield that the rule will be applied only to the extent necessary to accomplish its ostensible purpose-"to deter tliose engaged in felonies from killing negligently or accidentally." 60 Consistent witl this purpose, the court has restricted the scope of the rule to those felonies enumerated by statute or considered "inherently dangerous" to human life. ${ }^{61}$ Furtliermore, the court lias developed a "merger doctrime" under whiclı a felony that is also the act whicl resulted in death-for example, assault with a deadly weapon-may not serve as the predicate for a felony-murder charge. ${ }^{62}$ Finally, it has limited felons' liability for third-party killings by allowing convictions for felony-murder only in cases where the defendant or an accomplice caused the death. ${ }^{63}$

\section{B. Sentence Proportionality}

\section{The Federal Standard}

The eighth amendment to the United States Constitution prohibits the imposition of "cruel and unusual pumshments." The United States Supreme Court has determined that this prohibition applies not only to punishments that are cruel in their method, but also to those that are excessive for the offense committed. ${ }^{64}$ While past decisions leave open the possibility that the Court will find an inordimately long prison term

57. People v. Phillips, 64 Cal. 2d 574, 582, 414 P.2d 353, 360, 51 Cal. Rptr. 225, 232 (1966).

58. Id. at 583 n.6, 414 P.2d at 360 n.6, 51 Cal. Rptr. at 232 n.6.

59. People v. Washington, 62 Cal. 2d 777, 783, 402 P.2d 130, 134, 44 Cal. Rptr. 442, 446 (1965).

60. People v. Satchell, 6 Cal. 3d. 28, 34, 489 P.2d 1361, 1365, 98 Cal. Rptr. 33, 37 (1971); see also People v. Henderson, 19 Cal. 3d 86, 92-93, 560 P.2d 1180, 1183, 137 Cal. Rptr. 1, 4-5 (1977) (discussing scope of felony-murder rule).

61. See People v. Henderson, 19 Cal. 3d 86, 560 P.2d 1180, 137 Cal. Rptr. 1 (1977) (false imprisonment not "inherently dangerous" for purpose of felony-murder rule); People v. Lopez, 6 Cal. 3d 45, 489 P.2d 1372, 98 Cal. Rptr. 44 (1971) (escape not "inherently dangerous" felony); see also supra note 33 and accompanying text.

62. People v. Wilson, 1 Cal. 3d 431, 462 P.2d 22, 82 Cal. Rptr. 494 (1969); People v. Ireland, 70 Cal. 2d 522, 540, 450 P.2d 580, 590, 75 Cal. Rptr. 188, 198 (1969).

63. People v. Antick, 15 Cal. 3d 79, 539 P.2d 43, 123 Cal. Rptr. 475 (1975). The court still is willing to recognize liability for third-party killings where the defendant or his accomplice initiates a gun battle, e.g., Carlos v. Superior Court, 35 Cal. 3d 131, 672 P.2d 862, 197 Cal. Rptr. 79 (1983), or where the defendant takes a hostage who is killed by a third party while being used by the defendant as a shield, e.g., Pizano v. Superior Court, 21 Cal. 3d 128, 577 P.2d 659, 145 Cal. Rptr. 524 (1978). Yet these cases do not require application of the felony-murder rule, because the defendant's (or his accomplice's) conduct is evidence of a conscious disregard for a risk to human life- that is, the malice aforethought necessary for murder.

64. Weems v. United States, 217 U.S. 349 (1910). 
unconstitutional, ${ }^{65}$ it has generally been anxious to preserve for legislatures the role of determining criminal sanctions. ${ }^{66}$ The Court has largely confined its analysis to cases involving extraordinary penalties, qualitatively different from long terms of years-those involving loss of hife or permanent curtailment of civil liberties. ${ }^{67}$ Therefore, a defendant sentenced to a definite term of years has little hope that a court will find his sentence disproportionate under the federal standard..$^{68}$

Since the eighth amendinent applies to the states through the fourteenth amendment, ${ }^{69}$ sentences apphed in state criminal prosecutions must conform to botli federal and state proportionahty requirenents. In Solem v. Helm, ${ }^{70}$ the Supreme Court articulated a three-pronged test to guide states in assessing whether a penalty is proportionate to a defendant's culpability. ${ }^{71}$ The Court advised state tribunals (1) to examine objectively the gravity of the offense and the harshness of the penalty; (2) to coinpare the sentences imposed on other criminals in the same jurisdiction to determine whether more serious crimes are subject to the saine penalty or to less serious penalties; and (3) to compare the sentences imposed in other jurisdictions for commission of the same crime. $^{72}$

65. See id. at 381-82. In Weems, the Court held that 15 years of hard labor followed by the hifetime loss of citizenship privileges constituted cruel and unusual punishment for niaking a false entry on a public document. Id. at 381. Later decisions have viewed this punishment as something more that just a long term of years. See, e.g., Solem v. Helm, $103 \mathrm{~S}$. Ct. 3001, 3018 (1983) (Burger, C.J., dissenting); Rummel v. Estelle, 445 U.S. 263, 273-74 (1980); see also infra text accompanying note 67 .

66. Solem v. Helm, 103 S. Ct. 3001, 3009-10 \& n.16 (1983) (substantial deference must be accorded legislature); Rummel v. Estelle, 445 U.S. 263, 272-76 (1980) (courts should be "reluctan[t] to review legislatively mandated terms of imprisonment," and "successful challenges to the proportionahity of particular sentences" should be "exceedingly rare"); accord Hutto v. Davis, 454 U.S. 370, 374 (1982). This deference to legislativc judgment is refiected in a general reluctance to strike down penalties within the limits of a valid and constitutional statute.

67. The United States Supreme Court has apphed the eighth amendment to strike down punishments involving death, Enmund v. Florida, 458 U.S. 782 (1982); cadena temporal, which entails a long prison term of hard labor followed by lifetime loss of many civil rights, Weems v. United States, 217 U.S. 349 (1910); loss of citizenship, Trop v. Dulles, 356 U.S. 86 (1958); and life imprisonment without parole, Solem v. Helm, 103 S. Ct. 3001 (1983).

68. Compare Solem v. Helm, 103 S. Ct. 3001 (1983) (finding hfe iniprisonment without possibility of parole cruel and unusual for series of mimor felonies), with Rummel v. Estelle, 445 U.S. 263 (1980) (upholding a sentence of lifc imprisonment with possibility of parole for a series of minor felonies). The Solem majority was ablc to distinguish Rummel by finding the sentence of hife imprisonment without parole quahtatively different from life imprisonment wherc the defendant could be paroled. $103 \mathrm{~S}$. Ct. at 3015 . The Chief Justice, however, found this distinction to be without merit. Id. at 3017-21 (Burger, C.J., dissenting).

69. Robimson v. Cahfornia, 370 U.S. 660 (1962).

70. 103 S. Ct. 3001 (1983).

71. The term "culpability" is not a static concept, and courts may use the expression in ways that create confusion. In general, the term refers to the degree of guilt associated with particular conduct under a particular set of circumstances. See infra notes 87-88 and acconipanying text.

72. Solem, $103 \mathrm{~S}$. Ct. at 3010 . Applying these criteria in Solem, the Court held that the 


\section{California Law}

Article 1, section 17 of the California Constitution also prohibits "cruel or unusual punishments." In In re Lynch, ${ }^{73}$ the California Supreme Court held that a punishment violates this prohibition if "it is so disproportionate to the crime for which it is imflicted that it shocks the conscience and offends fundamental notions of human dignity."74 Striking down a penalty as disproportionate for the first time, the Lynch court established three techmiques for proportionahty analysis similar to those subsequently adopted by the United States Supreme Court in Solem v. Helm. ${ }^{75}$ The only significant difference between the two tests is that California courts enjoy broader discretion to tailor the analysis to a specific defendant by considering the particular defendant's redeeming personality traits. ${ }^{76}$

Both federal and California courts examine the marmer in which the defendant committed the charged offense, and the resulting degree of danger or actual harn. In undertaking this analysis they consider the seriousness or triviahty of the offense, the presence or absence of violence, the defendant's motive, and the extent of injury to the victim or society. ${ }^{77}$ Courts inay also review the defendant's past criminal history and weigh other factors indicative of the defendant's danger to

defendant who had been convicted for nttering a false check for $\$ 100$ and who had six other minor felony convictions could not be sentenced to life imprisonment without possibility of parole. Id. at 3012-16.

73. 8 Cal. 3d 410, 503 P.2d 921, 105 Cal. Rptr. 217 (1972).

74. Id. at 424,503 P.2d at 930,105 Cal. Rptr. at 226.

75. 103 S. Ct. 3001 (1983); see supra text accompanying note 72. Under the Lynch analysis the court first examines "the nature of the offense and/or offender, with particular regard to the degree of danger both present to society." Lynch, 8 Cal. 3d at 425, 503 P.2d at 930, 105 Cal. Rptr. at 226; see also infra text accompanying notes 77-79. Next the court compares the challenged penalty with the punishments prescribed in California for different, more serious, crimes. A penalty that is more severe than those prescribed for more serious offenses draws suspicion. $8 \mathrm{Cal} .3 \mathrm{~d}$ at 426, 503 P.2d at 932, $105 \mathrm{Cal}$ Rptr. at 228. Applymg the third techmique, the court coinpares the challenged penalty with the punishment prescribed for the same offense in other jurisdictions. The court is likely to strike down penalties that are mordinately long or severe in comparison to those prescribed for the same offense in other states. Id. at 427, 503 P.2d at 932, 105 Cal. Rptr. at 228.

76. Compare the objective factors listed by the United States Supreme Court in Solem, $103 \mathrm{~S}$. Ct. at 3011, see infra note 87, with the factors considered by the California Supreme Court in In re Rodriguez, 14 Cal. 3d 639, 537 P.2d 384, 122 Cal. Rptr. 552 (1975) and in People v. Dillon, 34 Cal. 3d 441, 668 P.2d 697, 194 Cal. Rptr. 390 (1983). In Rodriguez, the court noted that the defendant was meek and cooperative, and stressed that his offense could be explained by his low intelligence and feelings of sexual inadequacy. $14 \mathrm{Cal}$. 3d at $655 \& \mathrm{n} .19,537$ P.2d at 395-96 \& n.19, $122 \mathrm{Cal}$. Rptr. at 563-64 \& n.19. In Dillon, the court was impressed by the defendant's youth and immaturity. $34 \mathrm{Cal}$. 3d at 488, 668 P.2d at 727, $194 \mathrm{Cal}$ Rtpr. at 420. The United States Supreme Court necessarily exercises nore limited discretion to declare a given state's criminal punishments unconstitutional because the Court must accommodate the greatly varied penal philosophies and criminal systems of 50 states.

77. Solein v. Helm, 103 S. Ct. 3001, 3011 (1983); In re Lynch, 8 Cal. 3d 410, 425-26, 503 P.2d 921, 930-31, 105 Cal. Rptr. 217, 226-27 (1972). 
society. ${ }^{78}$ In addition, a California court may consider the defendant's age, his status as a drug addict, his character, and other subjective factors peculiar to the defendant. ${ }^{79}$

In applying the Lynch test, the California Supreme Court has shown a greater willingness than the United States Supreme Court to overturn statutory punishments. In Lynch, the court held that life imprisonment is too severe a penalty for second-offense indecent exposure. ${ }^{80}$ The court noted that: (1) the harm caused by the offense was minimal and the typical offender was nonviolent; (2) the penalty for second-offense indecent exposure was more severe than the penalties for arson, assault with intent to commit rape or sodomy, and several other more serious crimes; and (3) most states pumsh the same offense by no more than a short jail term and/or a small fine. ${ }^{81}$ In other cases, the court has used this three-tiered approach to find a twenty-two year sentence too long for lewd conduct with a child, ${ }^{82}$ preclusion of parole for ten years disproportionate to the crime of furnishing herom, ${ }^{83}$ and registration as a sex offender mappropriate for a defendant guilty of soliciting lewd and dissolute conduct. ${ }^{84}$ Thus, the court may not only scrutinize the length of prison terms, but it may apply proportionality analysis to virtually any type of criminal sanction. ${ }^{85}$

\section{Proportionality for Homicide Offenses}

\section{Measuring Culpability Outside of the Felony-Murder Rule}

Recognizing that punishment must bear some correlation with fault, courts endeavor to assign punishments that match defendants' levels of culpability. ${ }^{86}$ "Culpability" is a concept that has no rigid

78. Solem, 103 S. Ct. at 3011 ; Lynch, 8 Cal. 3 d at 425,503 P.2d at 930-31, 105 Cal. Rptr. at 226-27.

79. See, e.g., In re Rodriguez, 14 Cal. 3d 639, 537 P.2d 384, 122 Cal. Rptr. 552 (1975) (defendant relatively young and of low intelligence); In re Foss, 10 Cal. 3d 910, 519 P.2d 1073, 112 Cal. Rptr. 649 (1974) (addict furnishing heroin to feed habit less culpable than dealer selling to reap profit), disapproved on other grounds, People v. White, 16 Cal. 3d 791, 549 P.2d 537, 129 Cal. Rptr. 769 (1976).

80. 8 Cal. 3d at $438-39,503$ P.2d at 940,105 Cal. Rptr. at 236.

81. Id. at 429-36, 503 P.2d at 933-39, 105 Cal. Rptr. at 229-35.

82. In re Rodriguez, 14 Cal. 3d 639, 537 P.2d 384, 122 Cal. Rptr. 552 (1975).

83. In re Foss, I0 Cal. 3d 910, 519 P.2d 1073, 112 Cal. Rptr. 649 (1974), disapproved on other grounds, People v. White, 16 Cal. 3d 791, 549 P.2d 537, 129 Cal. Rptr. 769 (1976); see also In re Grant, 18 Cal. 3d 1, 553 P.2d 590, 132 Cal. Rptr. 430 (1976) (preclusion of parole for 10 years disproportionate punishınent for sale of marijuana).

84. In re Reed, 33 Cal. 3d 914, 663 P.2d 216, 191 Cal. Rptr. 658 (1983).

85. In the examples given above, the court reviewed not only the length of the sentence or the time before parole ehigibihty, but also considered the proportionahity of a penalty that involved hifelong registration as a sex offender. The nature of incarceration was a factor in Dillon, where the court was concerned that the defendant would be sent to prison rather than comnitted to the Youth Authority.

86. See Solem v. Helm, 103 S. Ct. 3001, 3006-07, 3011 (1983); see also id. at 3006 ("The 
meaning, ${ }^{87}$ but two salient factors predominate legal determinations of criminal culpability: the mental state of the offender and the magnitude of the crime or harm caused to the victim and society. ${ }^{88}$ The latter feature is static for all homicides; in every case the harm caused is of the highest inagnitude-the loss of a human life. Therefore, the measurement of culpability for homicide is based largely on an assessment of the defendant's mental state. ${ }^{89}$ Premeditated and deliberate homicides are considered the most reprehensible and are classified as murders of the first degree; unpremeditated intentional homicides and those committed with conscious recklessness are murders of the second degree; and imadvertent or careless homicides are not considered murder, but are pumshed less severely as involuntary manslaughter. ${ }^{90}$

Since the late sixteenth century, the distinction between willful and accidental homicide has been the basis for treating a person who has killed by misadventure differently from one who has killed intentionally. Accidental killings include those that are faultless or careless,

principle that a punishment should be proportionate to the crime is deeply rooted and frequently. repeated in common-law jurisprudence."); Weems v. United States, 217 U.S. 349, 367 (1910) ("[1]t is a precept of justice that punishment fo: crime should be graduated and proportioned to offense.").

87. In Solem v. Helm, for example, the Supreme Court found several factors relevant to a discussion of culpability. The factors imcluded the harm caused or threatened to the victim or society, whether the crime was violent or nonviolcnt, whether the defcndant caused physical injury to a person as opposed to causing damage to property, the absolute magnitude of the crime, and whether the crime was an attempt as opposed to a completed crime. $103 \mathrm{~S}$. Ct. 3001, 3011 (1983). The Dillon opinion discussed other, inore subjective factors such as the defendant's personality, the jury's reaction to him, and the light sentences given his accomphices. See supra text acconipanymg notes 21-22, 24; infra text accompanying notes 105-13. It is not clear whether the Dillon court found all of these factors necessary to an assessment of Dillon's culpabihity, or whether some of the factors were presented as further justification for the court's decision.

88. Most of the factors enunciated by the Solem Court relate in some way to the magnitude of the crime or luarm caused to the victim or society. See supra note 87 . The danger that a defendant represents to society is also based to some extent on the magnitude of the crimes he has committed or is expected to commit. That factor, however, is used not to determine the crime for which the defendant nuay be convicted, but is considered in ascertaining what punishment the defendant should receive among those assigned for his offense.

89. As used here, the tern "mental state" refers to the defendant's state of inind with rcspect to the homicide. The intent to commit a felony is, of course, a "mcntal state" that is often artificially transferred to the homicide under the felony-inurder rule. See supra text accompanying notes 27-28. The problein with using that process to determine the defendant's culpability for the homicide is that the defendant's actual mental state cannot be consistently equated with any of the other mental states associated with criminal homicide. See supra note 37.

90. W. LAFAVE \& A. SCOTT, supra note $26, \S \S 73,78$; see also infra text accompanying notes 9I-93; infra note 92. Not every state divides murder imto two degrees or makes the distinctions between first- and second-degree nuurder in the same manner. See, e.g., 18 PA. Cons. STAT. ANN. $\S 2502$ (Purdon 1983) (dividing murder into three degrees: premeditated unurder, felony murder, and all other murders). However, the division of nurder into two degrees is very common, and these distinctions enjoy a fairly broad base of support. See W. LAFAVE \& A. SCOTT, supra note $26, \S 73$ (discussing the division by most states of murder into two degrees). 
while willful killings include those that are intentional or reckless. ${ }^{91}$ The Model Penal Code further refines this standard, classifying homicides as purposeful, knowing, reckless, or negligent. ${ }^{92}$ Truly faultless homicides-those that occur inadvertently under lawful circumstances-are not subject to criminal punishment. ${ }^{93}$

\section{California's Penal Code}

The California Penal Code adopts the foregoing distinctions between the various mental states. It defines murder as "the unlawful killing of a human being, or a fetus, with inalice aforethought."94 Malice aforethought involves mental states associated with a high degree of culpability: willful premeditation, intent to kill, or a conscious disregard for an unreasonable risk to human life. ${ }^{95}$ Thus, murder requires a conscious decision to take, or at least risk, human life. The higher the level of consciousness of the decision, the higher the degree of culpability, and the greater the severity of the punishment imposed. California pumishes first-degree murder, which involves willful premeditation, by death, life imprisonment without possibility of parole, or twenty-five years to life in prison. Second-degree murder, which includes imtentional and reckless homicides, is pumishable by fifteen years to life. ${ }^{96}$

Involuntary manslaughter, on the other hand, mvolves the lowest degree of culpability generally thought necessary for criminal liability-gross or criminal neghigence. ${ }^{97}$ Unlike murder pumshments,

91. See generally Robinson, A Brief History of Distinctions in Criminal Culpability, 31 HasTINGS L.J. 815 (1980).

92. Model Penal Code §§ 2.02(2), 210.1 (Proposed Official Draft 1962). The Code describes a homicide as murder if it is committed "purposely or knowingly" or "recklessly under circuunstances manifesting extreme indifference to the value of human life." Id. \$210.2. A negligent homicide is equivalent to involuntary manslaughter-that is, one committed under circunstances involving a "gross deviation from the standard of care that a reasonable person would observe in the actor's situation." Id. $\$ \S 2.02(2)(\mathrm{d}), 210.4$. The Code also distinguishes homicides involving ordinary recklessness froin those involving recklessness manifesting extreme indifference to human life and designates the former manslaughter. $I d . \$ \S 210.2,210.3$.

93. Robinson, supra note 91, at 835-36.

94. Cal. Penal Code $\$ 187$ (West Supp. 1984).

95. See generally People v. Conley, 64 Cal. 2d 310, 411 P.2d 911, 49 Cal. Rptr. 815 (1966).

96. Cal. Penal Code $\& 190$ (West Supp. 1984).

97. Id. $\S 192$; see also id. $\S 20$ (West 1970) ("II]n every crime or public offense there must exist a union or joint operation of act and intent, or criminal negligence."). Gross negligence is not cnough to constitute the impled malice necessary for murder. See People v. Watson, $30 \mathrm{Cal}$. 3d 290, 637 P.2d 279, I79 Cal. Rptr. 43 (1981), explaining the difference as follows:

[GJross negligence . . . has been defined as the exercise of so slight a degree of care as to raise a presumption of conscious indifference to the conscquences. On the other hand, malice inay be implied when a person, knowing that his conduct endangers the life of another, nonetheless acts deliberately with conscious disregard for life. Though these definitions bear a general similarity, they are not identical. Implied malice contemplates a subjective awareness of a higher degree of risk than does gross negligence, and involves an element of wantonness which is absent in gross negligence.

Furthermore, ... [a] finding of gross neghigence is made by applying an objective 
which are severe and indeterminate, the punishment for manslaughter is finite and relatively mild. The base terms for involuntary manslaughter are two, three and four years. ${ }^{98}$ Thus, the significant difference in mental state and corresponding reduction in associated culpability is reflected by a substantial quantitative and qualitative difference in punishment.

\section{III}

\section{Dillon AND the Demise of California's Felony- MURDER RULE}

The Dillon decision is significant because it indicates that a court may invoke the state constitutional prohibition against cruel or unusual punishment to expand greatly the role of sentence proportionality analysis in California. The new approach allows a court unprecedented discretion in adjusting criminal sanctions to fit its own notions of just punishment. ${ }^{99}$ The California Supreme Court has indicated that it is willing to examine the proportionality of noncapital penalties, even where the gravity of the defendant's offense is very serious and his conduct results in death. Moreover, the court has given to critics of the felony-inurder rule new hope that the rule's deinise may yet be at hand.

\section{A. The Dillon Approach to Proportionality Analysis}

Dillon signals a departure from the court's previous practice of limitimg proportionality analysis to cases involving clearly disproportionate punishment. It is the first time that the court has indicated that its analysis under the first Lynch technique will go beyond a gross assessment of the seriousness of the conduct as measured against the severity of the punishment.

In prior cases, the disparity between the gravity of the conduct and the severity of the penalty has been fairly obvious. In $L y n c h$, a trivial offense-imdecent exposure-was punished by a very severe penaltylife imprisonment. ${ }^{100}$ In In re Reed, a trivial offense-soliciting lewd and dissolute conduct froin an undercover officer-was punished by

test: if a reasonable person in defendant's position would have been aware of the risk involved, then the defendant is presumed to have had such an awareness. However, a finding of implied malice depends upon a determination that the defendant actually ap. preciated the risk involved, i.e., a subjective standard.

Id. at 296-97, 637 P.2d at 283, 179 Cal. Rptr. at 47 (empliasis in original) (citations omitted).

98. Cal. Penal Code $\S 193$ (West Supp. 1984).

99. As Justice Richardson noted, the court had never before modified a conviction without finding error. In his view, "inodification of the judgment in reliance on the cruel or unusual punishment clause constitute[d] an unwarranted invasion ... of the powers of the Legislature . . . and of the Governor." Dillon, 34 Cal. 3d at 499, 668 P.2d at 734-35, 194 Cal. Rptr. at 427 (Richardson, J., concurring and dissenting).

100. In re Lynch, 8 Cal. 3d 410, 503 P.2d 921, 105 Cal. Rptr. 217 (1972). The penalty was an 
the stigna of lifelong registration as a sex offender. ${ }^{101}$ And in In re Grant, In re Foss, and People v. Schueren, the offenses were of medium severity while the punishments were extreinely harsh. ${ }^{102}$ Even in In re Rodriguez, where the offense-child inolestation-was fairly serious, the life-inaximum sentence was clearly disproportionate to the defendant's nonviolent conduct. ${ }^{103}$

In Dillon, by contrast, the state attempted to punish a very serious offense-intentional robbery inurder-with a very severe penalty-life imprisonment. Thus, a gross characterization of Dillon's conduct was not sufficient to show that the penalty was shockingly disproportionate. Consequently, the court needed to refine its analysis. It conceded that the offense was very serious, but noted that it was not the inost serious offense the defendant might have committed. Yet, the pumshment imposed was the most severe that the particular defendant could have received. ${ }^{104}$ The decision thus signaled that the California Constitution requires a fairly precise fit between the crime, the criminal, and the pumishment.

Dillon also reveals that the court may support its proportionality analysis with considerations other than those traditionally associated with sentencing decisions. Although jury syinpathy has been a factor in capital pumishment decisions, ${ }^{105}$ the jury generally does not have a role in other sentencing determinations. ${ }^{106}$ Yet jury sympathy was an

indeterminate one year to life in prison which the court considered a life sentence for the purpose of determining its constitutionality. Id. at 415-18, 503 P.2d at 924-26, 105 Cal. Rptr. at 220-22.

101. In re Reed, 33 Cal. 3d 914, 663 P.2d 216, 191 Cal. Rptr. 658 (1983).

102. In re Grant, 18 Cal. 3d 1, 553 P.2d 590, 132 Cal. Rptr. 430 (1976) (minimum term of 10 years for sale of marijuana); In re Foss, 10 Cal. 3d 910, 503 P.2d 1073, 112 Cal. Rptr. 649 (1974) (minimum term of 10 years for second offense of furnishing heroin where minimum term for third offense of murder was 9 years), disapproved on other grounds, People v. White, $16 \mathrm{Cal} .3 \mathrm{~d}$ 791, 796 n.3, 549 P.2d 537, 541 n.3, 129 Cal. Rptr. 769, 773 n.3 (1976) (stating that the Foss court had miscalculated the minimum term); People v. Schueren, 10 Cal. 3d 553, 516 P.2d 833, $111 \mathrm{Cal}$. Rptr. 129 (1973) (life-maximum sentence for assault with a deadly weapon where maximum penalty for assault with a deadly weapon with intent to commit inurder was 14 years).

103. In re Rodriguez, 14 Cal. 3d 639, 537 P.2d 384, 122 Cal. Rptr. 552 (1975) (life-maximum, 22 years served for nonviolent child molestation).

104. Dillon, 34 Cal. 3d at 487, 668 P.2d at 726, 194 Cal. Rptr. at 419.

105. Prior to the 1978 death penalty mitiative, sentencing of defendants convicted of first degree murder was governed by former $\$ 190.1$ of the Penal Code, which provided that "[t]he determination of the penalty of life imprisonment [or death] shall be in the discretion of the court or jury." Cal. Penal Code $\S 190.1$ (West 1970) (emphasis added) (repealed by mitiative 1978). Under current law, the trier of fact is instructed to "consider, take into account and be guided by" evidence of aggravating and mitigating circumstances, and must impose a sentence of death if "the aggravating circumstances outweigh the mitigating circumstances." CAL. PENAL CODE $\S 190.3$ (West Supp. 1984). The jury may still consider any sympathy factors raised by the evidence. People v. Easley, 34 Cal. 3d 858, 876, 671 P.2d 813, 824, 196 Cal. Rptr. 309, 320 (1983) (error to instruct jury during penalty phase of capital case that it must not be "influenced by pity" or "swayed by mere sentiment [or] sympathy" for the defendant).

106. Under California's prior system of indeterminate sentences, the term of imprisonment 
important factor in the Dillon court's decision. ${ }^{107}$ The court also expressed concern that Dillon had received a more severe penalty than he or the jury had expected. ${ }^{108}$ But sentencing authorities do not traditionally consider the defendant's expectations when fixing punishment. Finally, the court placed emphasis on the relatively light sentences received by Dillon's accomplices. ${ }^{109}$ While disparity of sentencing is a problem in the field of criminal procedure, ${ }^{110}$ it is not ordmarily a problein of constitutional dimension, particularly where the defendant is more culpable than his accomplices. ${ }^{111}$ The disparity in this case can be explained by Dillon's greater level of participation in both the attempted robbery and the killing, by the exercise of prosecutorial discretion, and by the results of the other defendants' plea bargaining. ${ }^{112}$

Most sigmificantly, Dillon seems to indicate that a strong sliowing of disproportionality based on a subjective assessinent of the defendant's personal characteristics may compensate for a weak or questionable showing under otlier aspects of the Lynch analysis. Only the court's subjective assessment of Dillon's character and the danger that he presented to society yielded a strong indication that his pumshment might be too severe. ${ }^{113}$ The court did not support by reference to the Penal Code or any other authority its determination that intentional robbery murder is less serious than unaggravated premeditated murder. ${ }^{114}$ But, assuming that this determination is valid, once the mtent to

was not fixed initially by the trial court or the jury, CAL. PENAL CoDE $\$ 1168$ (West 1970) (repealed 1978), but was determined after the expiration of the ininimum term by the Board of Prison Terms and Paroles. Id. at historical note. The authority to fix terms of imprisonment is now vested in the trial court, subject to statutory limitations and the sentencing rules of the Judicial Couucil. See generally CaL. Penal Code $\$ \S 1170-1170.8$ (West Supp. 1984).

107. Dillon, 34 Cal. 3d at 484-85, 668 P.2d at 724-25, 194 Cal. Rptr. at 417-18.

108. Id. at 486,668 P.2d at 725-26, 194 Cal. Rptr. at 419. Although the trial court committed Dillon to the Youth Authority, the court of appeal leeld in People v. Superior Court (Dillon), 115 Cal. App. 3d 687, 185 Cal. Rptr. 290 (1981), that at the time of his offense Dillon was ineligible for the Youth Authority as a matter of law.

109. Dillon, 34 Cal. 3d at 448, 668 P.2d at 727, 194 Cal. Rptr. at 420.

110. The shift to determinate sentencing in California was, in part, aimed at the elimmation of this problem. See CAL. PENAL CODE $\S 1170$ (West Supp. 1984) (statimg that the elimination of sentence disparity is one of the purposes of the statute).

111. See, e.g., Hedrick v. United States, 357 F.2d 121, 124 (10th Cir. 1966) (five-year sentcnce for tax fraud not cruel and unusual punishment for accountant where codefendant chent sentenced to only five months); McGowen v. State, 221 Tenn. 442, 454, 427 S.W.2d 555, 560 (1968) (five-year sentence for arson not cruel and unusual punishment under Tennessee Constitution where codefeudant received six-month sentence). In both of these cases, as im Dillon, there was evidence tending to slow that the defendant liad conceived the crine.

112. See supra note 24.

113. Dillon, 34 Cal. 3d at 486, 668 P.2d at 725, 194 Cal. Rptr. at 419.

114. In fact, $\S 190.2$ seems to contradict this assessment by including intentional robbery murder, but not unaggravated premeditated inurder, among the special circumstances that autliorize imposition of the death penalty. CAL. PenAL CODE $\$ 190.2$ (West Supp. 1984); see supra note 54 and accompanying text. However, the Dillon court's interpretation finds some support in 
kill is shown, the intent to commit robbery arguably raises the defendant's culpability to a level close to that of premeditation. Consequently, despite the majority's mild characterization of the facts, an examination of the offense revealed a relatively close correlation between the seriousness of the conduct and the severity of the punishment.

The showing of disproportionality under the second Lynch technique was equally tenuous. The court could not find a more serious crime that was punished less severely, and instead noted that Dillon's punishment was as severe as it would have been for a inore serious crime. ${ }^{115}$ Finally, the court made no atteinpt to show disproportionality under the third techmique. ${ }^{116}$

The Dillon analysis allows courts a degree of flexibility and discretion that potentially could affect any area of crimmal law where liability is not closely related to individual culpability. In the past, the court has used proportionality analysis to mitigate the effects of harsh indeterminate penalties apphied to wide ranges of conduct. ${ }^{117}$ This problein has largely disappeared because of the legislative shift to determinate sentences. ${ }^{118}$ However, proportionality analysis will contimue to have an impact on acconiphice hability and conspiracy cases, where hability often exceeds the scope of intended or actual participation. ${ }^{19}$

Of course, the most significant contribution of the Dillon decision is its indication that proportionality analysis applies to felony murder at all. Prior to Dillon, courts might have assumed that a person coinmitting a designated or inherently dangerous felony creates a high

Pennsylvania's criminal statutes where prenneditated inurder is murder of the first degree and felony inurder is murder of the second degree. 18 PA. Cons. STAT. ANN. $\$ 2502$ (Purdon 1983).

115. Dillon, 34 Cal. 3d at 487 n.38, 668 P.2d at 726 n.38, 194 Cal. Rptr. at 419 n.38.

116. Id.

117. See, e.g., In re Rodriguez, 14 Cal. 3d 639, 537 P.2d 384, 122 Cal. Rptr. 552 (1975) (one year to the); People v. Schueren, 10 Cal. 3d 553, 516 P.2d 833, 111 Cal. Rptr. 129 (1973) (six months to life); In re Lynch, 8 Cal. 3d 410, 503 P.2d 921, 105 Cal. Rptr. 217 (1972) (one year to hife).

118. See generally CAL. PenAl CODE $\S 1170$ (West Supp. 1984) (legislature finds that elimination of sentence disparity best achieved by determinate sentences fixed by statute).

119. Under Cahifornia law, all persons "concerned in the commission of a crime" are considered primcipals and are hable for punishment as such. CAL. PENAL CoDE $\S 31$ (West 1970). Thus, common law distinctions between principals of the first and second degree, aiders and abettors, and accessories before the fact are immaterial. The term "accessory" is limited to those who do not participate directly in the crime, but who aid, harbor or conceal a principal after a felony has been committed with the imtent that the principal avoid or escape arrest. Id. \$32. In addition, each inember of a criminal conspiracy is criminally hable for all acts of his coconspirators coinmitted pursuant to the common design or plan, People v. Weiss, 50 Cal. 2d 535, 563, 327 P.2d 527, $543-44$ (1958), disapproved on other grounds, People v. Johnson, 26 Cal. 3d 557, 606 P.2d 738, 162 Cal. Rptr. 431 (1980); People v. Harper, 25 Cal. 2d 862, 871, 156 P.2d 249, 254 (1945), even if those acts were nnintended or forbidden by the conspirator. People v. Beaumaster, 17 Cal. App. 3d 996, 1003, 95 Cal. Rptr. 360, 364 (1971). 
enough risk to deserve harsh punishment. ${ }^{120}$ Dillon precludes this abstract rationale for enhanced punishment by focusing on individual conduct and the actual circuinstances of the crime. Dillon directs courts to consider "the totality of the circumstances surrounding the commission of the offense . . . including such factors as its motive, the way it was committed, the extent of the defendant's mvolvement, and the consequences of his acts." 121 This approach should bring felonyinurder penalties into line with those that would be imposed if the felony-murder rule were not applied. Thus, the degree-fixing aspect of the felony-murder rule can no longer apply automatically. In Dillon, the court allowed the defendant to be punished only for second-degree inurder, the crime for which he presumably would have been convicted absent application of the first-degree felony-inurder rule. ${ }^{122}$

The Dillon approach could also require changes in enforcement of the felony-inurder rule. The rule now applies only to enumerated felonies and to those that have been designated as "inherently dangerous." ${ }^{23}$ Given Dillon's emphasis on actual conduct, courts may hmit the rule even further-precluding its application even in cases where the crime in the abstract is inherently dangerous unless the defendant's actual conduct is dangerous. This limitation would be most significant to felons killing accidentally or neghigently in the course of minor burglaries or unarmed robberies. Dillon's focus on individual culpability and the defendant's involvement suggests that felony-murder accomplices must be punished accordimg to their participation im the killing, not just their involvement $\mathrm{n}_{1}$ the underlymg felony. Moreover, if proportionate sentencing requires courts to consider the totahity of the circumstances, defenses that wonld not ordmarily apply in felony-murder

120. This is, in fact, one of the justifications advanced by early California courts for the felony-inurder rule. Rather than holding that malice was not an eleinent of felony murder, the courts held that the intent to commit a dangerous felony was equivalent to a reckless disregard for human life. See, e.g., People v. Milton, 145 Cal. 169, 171-72, 78 P. 549,550 (1904) (1nalice of an abandoned and malignant heart is shown by the very nature of the felony). At best, such a theory supports only a limited version of the felony-murder rule. As the California Supreme Court recently noted,

"I] nstead of saying that any act done with intent to commit a felony and which causes death amounts to inurder, it would be reasonable to say that any act known to be dangerous to life, and likely in itself to cause death done for the purpose of committing a felony which caused death, should be murder."

People v. Burroughs, 35 Cal. 3d 824, 842-43, 678 P.2d 894, 907, 201 Cal. Rptr. 319, 332 (1984) (Bird, C.J., concurring) (reversing second-degree felony-murder conviction for death resulting froin felonious unlicensed practice of medicine) (quoting Regina v. Serne, 16 Cox Crim. Cas. 311, 313 (Eng. 1887)).

121. Dillon, 34 Cal. 3d at 479, 668 P.2d at 720, 194 Cal. Rptr. at 413-14.

122. It is not clear that Dillon would have been convicted of second-degree murder because the jury did not reach that issue. However, the jury would have had difficulty ignoring the evidence that the killing was intentional, whether or not it was induced by panic.

123. See supra notes 33,61 and accompanying text. 
cases, such as self-defense, accident, or heat of passion, may now be available. In Dillon, for example, the court considered Dillon's apparent pamic in deciding to mitigate his pumshment, even though he was attempting to commit a felony against his victim. ${ }^{124}$

As the Dillon court acknowledged, " in almost all cases in which [the felony-murder rule] is applied it is unnecessary." "125 Most such cases imvolve an imtentional or reckless killing already amountimg to murder. In cases where the killing is accidental or negligent, the rule results in harsh penalties that bear hittle relation to the defendant's culpability. Consequently, should the court apply the Dillon analysis to felony-1nurder cases im general, it would find that where the rule is necessary to secure conviction, the resulting penalty imevitably will be disproportionate and therefore unconstitutional.

\section{B. Implications of the Dillon Analysis}

Dillon, then, advocates a refined proportionality analysis under the first Lynch techmique. This refined approach requires a close correlation between the court's assessment of the defendant's culpability and the assigned pumshment. Dillon also allows a finding of disproportionate pumishment under the second Lynch techmique if there is a more serious offense that is punished as severely, even if more serious offenses are not punished less severely. The Dillon test thus lowers the threshold for a finding of disproportionality.

The requisite correlation between culpability and punishment and the lowered threshold for a finding of disproportionate punishment dislodge the basic underpinnings of the felony-murder rule. After Dillon, the state may not, consistent with California's prohibition agamst cruel or unusual punishment, punish as murderers felons who commit what would otherwise be involuntary manslaughter. Since the purpose of the felony-murder rule is to punish imvoluntary manslaughter as murder, the rule is inconsistent with California's constitution and should be declared void.

It is not immediately apparent that Dillon stands for the principle that only acts that are otherwise murder can be punished as felony murder. Dillon involved a killing that was already murder; the court did not have to decide what punishment is appropriate where the killing involves less culpable mental states. Moreover, the court held that malice is not an element of felony murder, and malice is the basis of distinction between murder and less serious homicides. Thus, eliminat-

124. 34 Cal. 3d at 488, 668 P.2d at 727, 194 Cal. Rptr. at 420 .

125. Id. at 463, 668 P.2d at 709, 194 Cal. Rptr. at 402 (quoting People v. Washington, 62 Cal. 2d 777, 783, 402 P.2d 130, 134, 44 Cal. Rptr. 442, 446 (1965)). 
ing malice as an eleinent of felony murder seeins to clear the way for punishing nonmurders as inurder.

Yet, despite its rejection of a malice requirement, the court based its modification of Dillon's conviction largely on an assessment of his inental state. The court did not allow Dillon's felomous intent to bridge the gap between intent to kill and premeditation. The Dillon court held, in effect, that an intentional killing that results in part from panic should not be punished as first-degree murder, even if it occurs during an atteinpt to commit an enumerated felony. Thus, Dillon at least supports the proposition that a felony killing that results from accident, negligence, or even gross negligence slould not be punishcd as first-degree murder.

Dillon does not explicitly prevent courts froin merely lowering the judginent in sucl cases from first- to second-degree murder. However, the Dillon decision suggests that courts should require a sufficient showing of culpability with respect to the lomicide before allowing imposition of any inurder penalties. Since all lomicides result in the loss of human life, the culpability associated with a particular homicide is virtually synonymous witl the defendant's mental state. ${ }^{126}$ The significant difference in the mental state required for inurder compared to that associated with involuntary nanslaughter results in a substantial difference in culpability. The intent to commit the underlying felony cannot eliminate this difference. Consequently, the penalties for murder are grossly disproportionate when the defendant has committed what otherwise amounts to mvoluntary inanslaugliter.

\section{Applying the Dillon Standard}

Two cases, not decided by the California Supreme Court, will illustrate the difference that the Dillon proportionality analysis can inake. Consistent with Dillor's first techinque, the examination will focus on the defendants' levels of culpability, and will compare the norinal range of punishment for that level of culpability with the punishment actually received. Under the second Dillon techinque, the defendants' punishinents will be balanced against the punishinents received for comparable and inore serious crimes. ${ }^{127}$

\section{a. People v. Stamp}

The prototypical example of an accidental felony-murder case is People v. Stamp. ${ }^{128}$ In Stamp, the defendants had robbed an amuseinent company while arıned with a gun and a blackjack. In the course

126. See supra text accompanying note 89 .

127. The third technique will not be used because it was not used by the Dillon court.

128. 2 Cal. App. $3 d$ 203, 82 Cal. Rptr. 598 (1969), cert. denied, 400 U.S. 819 (1970). 
of the robbery, they forced everyone to lie down on the floor and, as they left, told the victims to stay there so that no one would "get hurt."129 The defendants left the scene without shooting or striking anyone. Nevertheless, fifteen minutes after the robbery, an obese sixtyyear-old victim with a history of heart disease died of a heart attack. The defendants were convicted of first-degree felony unurder and given life sentences. ${ }^{130}$

An examination of the defendants' conduct reveals that they acted no worse than most other bank robbers and they engaged in no gratuitous violence. Once the notion that all armed robberies pose an unreasonable risk to human life is discarded, ${ }^{131}$ it cannot be said that the defendants in Stamp consciously took or risked human life. Their culpability, based on conduct and inental state, is less than that associated with murder. The only objective basis upon which to find them nore culpable than other bank robbers is that they caused greater, though unforeseeable, harm to the victim.

Nevertheless, the fact that the victim died does not, by itself, justify treating the offense as inurder, because the law does not treat all unlawful killings as murder. The death occurred under unlawful circumstances, but it was still accidental. Absent the felony-murder rule, these defendants probably would have been convicted of robbery and involuntary inanslaughter. Under normal sentencing rules, the penalty for robbery using a firearm - seven years-wonld be increased by one year for imvoluntary manslaughter to a total penalty of eight years. ${ }^{132}$ Thus, the first Dillon technique reveals that life imprisoument is a disproportionate penalty.

Under the second Dillon technique, the court would compare the defendants' sentences with those for comparable and for more serious

129. Id. at 207-08, 82 Cal. Rptr. at 601 .

130. Id. at 207,82 Cal. Rptr. at 600 .

131. See supra note 39.

132. This calculation assumes that neither defendant had a prior criminal history. It also ignores the traces of the felony-murder rule that appear throughout the California Penal Code, mcluding qualifications in the definition of involuntary manslaughter that refer to unlawful conduct "not amounting to a felony." Cal. Penal Code $\S 192$ (West Supp. 1984). Conseeutive sentences for multiple felomies are determined by adding a base term equal to the term for the most sevcrely punished crime (including enhancements) to a subordinate tern determined by adding one-third of the middle tern of each additional felony. Id. \& 1170.1. In this case the upper term for robbery (two, three or five years) is enhanced by two years for use of a firearm and added to one-third the middle term for imvoluntary manslaughter (two, three or four years). Id. $\$ \S 193$, $213,12,022.5$. The Code allows a felon's sentence to be enhanced by three years where his victim suffers great bodily ijjury. Id. $\$ 12,022.7$ (West 1982). An appropriate alternative to the felonymurder rule might be a five-year sentence enhancement for an accidental or negligent death resulting from the commission of a felony. Reckless and intentional deaths would continue to be punished as murder even without the felony-murder rule. See supra text accompanying notes 9495. 
crimes. A premeditated killing would receive the same penalty, ${ }^{133}$ and an intentional but unpreineditated killing during a kidnapping would receive less severe punishment. ${ }^{134}$ Thus, the second technique also reveals that the punishnent is disproportionate.

\section{b. People v. Fuller}

The rigid techmicalities of the felony-murder rule may result im highly anomalous sentencing. People v. Fuller ${ }^{135}$ is a case im point. In Fuller the two defendants had burglarized four. Dodge vans im a car lot and stolen the spare tires. Police spotted them leaving the scene of the crime, and a high-speed chase ensued. The defendants drove througli a red light, causing a fatality. ${ }^{136}$ Because flight from a crime is considered part of the crime, ${ }^{137}$ the court of appeal held that the defendants could be prosecuted for first-degree felony murder. ${ }^{138}$

Under the first Dillon techmique, it is clear that the defendants, like the defendants in Stamp, did not have the inental state necessary for murder. The felony that they had committed was a second-degree burglary involving no danger to liunian life. The killing resulted from negligent driving by one of the defendants. ${ }^{139}$ While a court might conclude that negligent driving involves more culpability when done to evade the police, second-degree burglary is not always treated as a felony, ${ }^{140}$ and escape will not otherwise support a felony-murder convic-

133. Cal. Penal Code $\S 189$ (West Supp. 1984).

134. Since kidnapping is not one of the felonies enunierated in $\S 189$ of the Penal Code, an unpremeditated murder committed during a kidnapping is second-degree inurder. Id.

135. 86 Cal. App. 3d 618, 150 Cal. Rptr. 515 (1978).

136. Id. at $621-22,150 \mathrm{Cal}$. Rptr. at 516 .

137. Flight following the commission of a felony is considered part of the felony as long as the felon has not reached a place of temporary safety. People v. Salas, 7 Cal. 3d 812, 821-22, 500 P.2d 7, 14, 103 Cal. Rptr. 431, 437-38 (1972), cert. denied, 410 U.S. 939 (1973).

138. Fuller, 86 Cal. App. 3d at 628,150 Cal. Rptr. at 520.

139. The trial court and the court of appeal disagreed as to whether there was enough evidence of reckless driving to convict the defendants of second-degree inurder. Compare id. at 62829, 150 Cal. Rptr. at 520-21 (stating that the defendants could be charged with second-degree unurder), with id. at 621,150 Cal. Rptr. at 516 (indicating that the trial court had disinissed the murder charge and amended the infornatiou to substitute a vehicular-manslaughter charge).

140. See Cal. Penal Code $\S \S 17,461$ (West Supp. 1984). Section 17 defines a felony as any offense punishable by death or imprisonment in state prison for inore than one year. Section 461 allows second-degree burglary to be punished by imprisonment in state prison, or by a jail terun of one year or less. When the lower penalty is assigned, second-degree burglary is considered a misdemeanor. See also In re Kenneth H., 33 Cal. 3d 616, 619, 659 P.2d 1156, 1158, 189 Cal. Rptr. 867,869 (1983) (indicating that second-degree burglary can be treated as a felony or misdemeanor). A death resulting from the commission of a misdemeanor ("unlawful act not amounting to a felony") is involuntary inanslaughter. CAL. PENAL CODE $\S 192$ (West Supp. 1984). Given the insignificant difference in the levels of culpability for many minor felonies and nisdemeanors, there is no justification for treating a resulting death as inurder in one case and as involuntary inanslaughter in another. 
tion. ${ }^{141}$ Moreover, the court acknowledged that the punishment seemed mappropriate, and stated that it had reached its decision only by rigid application of precedent. ${ }^{142}$

Application of the second Dillon techmque confirms a finding of disproportionahity. Had the defendants been fleeing from a more serious crime not considered inherently dangerous-grand larceny, for example-they would have been guilty of only vehicular manslaughter. ${ }^{143}$ In fact, if the defendants had been in a high-speed chase after stealing the vans rather than the spare tires, the grand-theft charge would not have supported a felony-murder conviction. ${ }^{144}$ The inaximum penalty for vehicular inanslaughter is six years and for grand theft is one year in prison. ${ }^{145}$ Thus the penalties for first-degree nuurder are disproportionate to the culpability of the Fuller defendants.

\section{Drawing the Line Between Murder and Manslaughter}

There are, of course, cases in which it is not clear that the defendant committed inanslaughter instead of inurder. That is, the inore reckless the defendant's behavior, the niore appropriate a second-degree murder penalty becoines. Further, if the killing appears intentional or premeditated, first-degree nuurder penalties are appropriate. The felony-murder doctrine is most problematic with close cases. If an offense is "alinost" murder, is it then consistent with our notions of justice to impose inurder punishments?

A look at our system of justice outside the context of felony inurder is instructive. Under no other circumstance is a inurder penalty imposed for involuntary nianslaughter. Instead, a defendant's behavior must support an inference of "wanton disregard for [an unreasonable risk to] human life" before even second-degree murder penalties are considered appropriate. ${ }^{146}$

141. See People v. Lopez, 6 Cal. 3d 45, 489 P.2d 1372, 98 Cal. Rptr. 44 (1971) (felony-murder rule does not apply to prison escapes).

142. People v. Fuller, 86 Cal. App. 3d 618, 626-28, 150 Cal. Rpts. 515, 519-20 (1978).

143. Grand larceny is not an "inherently dangerous" felony and it is not subject to the felonymurder rule. People v. Phillips, 64 Cal. 2d 574, 414 P.2d 353, 51 Cal. Rptr. 225 (1966). Burglary, which is classified as inherently dangerous, originally referred only to breaking into a dwelling house at night. See supra note 38 .

144. See People v. Fuller, 86 Cal. App. 3d 618, 626, 150 Cal. Rptr. 515, 519 (1978).

145. Cal. Penal Code $\$ \S 193,489$ (West Supp. 1984). Like second-degree burglary, vehicular manslaughter and grand theft can be punished by one year or less in county jail and can, therefore, be treated as misdemeanors. Id. $\$ \S 193,461$, 489; see also supra note 140.

146. See California Jury Instructions CRiminal [CALJIC] 8.10 (West 1979 \& Supp. 1984) (defining murder as an unlawful killing with malice aforethought); $i d .8 .11$ (brackets omitted): being.

Malice is express when there is manifested an mtention unlawfully to kill a human Malice is implied when the killing results froin an intentional act involving a ligh 
Dillon implies that the same distinction is appropriate in the context of felony-murder punishments. If the totahity of circumstances surrounding a homicide indicates that the defendant consciously subjccted a human life to unreasonable risk, then murder punishments are justified. If the defendant's conduct does not suggest recklessness or an mtent to kill, then the defendant's culpability is insufficient to invoke murder penalties.

Thus, the felony-murder rule is, as courts and commentators have often stated, unnecessary where it is appropriate, and mappropriate where it is necessary for a murder conviction. ${ }^{147}$ The court will have a constitutional basis for declaring the rule void once it acknowledges that the felony-murder rule is not merely a barbaric anachronism, but that it invariably results in disproportionate penalties whenever its use is necessary.

The Califorina Supreme Court has often declared that the felonymurder rule has but one purpose-to deter felons from killing in the course of felomies by holding them strictly responsible for inurder when a death results from their actions. ${ }^{148}$ The rule cannot accomphsh this purpose unless its application results im penalties for felony homicides that are appreciably more severe than the penalties that otherwise would result. Yet the Dillon court has forbidden this result by requiring that felony-inurder punishments conforn to the notion of proportionate punishment that applies in other contexts. The court has declared, in effect, that the felony-murder rule can no longer serve its intended purpose without violating the state constitution.

\section{CONCLUSION}

The Dillon decision is paradoxical. Dillon rejects judicial abrogation of the felony-murder rule and finds the rule valid under a dueprocess challenge, while simultaneously laying the groundwork for its destruction on another constitutional basis. Moreover, Dillon poimts out the mcompatibility of the felony-murder rule with the constitu-

degree of probability that it will result in death, which act is done for a base, anti-social purpose and with a wanton disregard for human life.

147. See Model Penal Code $\$ 201.2$ comment 4 (Tent. Draft No. 9, 1959); Packer, The Case for Revision of the Penal Code, 13 STAN. L. REv. 252, 259 (1961); see also supra text accoinpanying notes 36-44.

148. See, eg., People v. Washington, 62 Cal. 2d 777, 781, 402 P.2d 130, 133, 44 Cal. Rptr. 442, 445 (1965) ("The purpose of the felony-inurder rule is to deter felous from killing negligently or accidently by holding them strictly responsible for killings they commit."); see also People v. Satchell, 6 Cal. 3d 28, 34, 489 P.2d 1361, 1365, 98 Cal. Rptr. 33, 37 (1971) (the concept of "strict criminal liability . . . m the felony-murder doctrine [should] be given the narrowest possible apphication consistent with its ostensible purpose-which is to deter those cngaged in felonies from killing negligently or accidentally . . . "); accord People v. Henderson, 19 Cal. 3d 86, 92-93, 560 P.2d 1180, 1183, 137 Cal. Rptr. 1, 4 (1977). 
tional requirement that punishment be proportionate to the crime. The felony-murder rule results in disproportionate punishment because that is its very purpose. It ignores the differences in culpability that are at the heart of the assignment of homicide penalties. Dillon's message is that those differences must be considered, even where the felony-murder rule is apphed, in order to keep punishments withm constitutional limits. If the Dillon analysis is carried to its logical conclusion, the court must find that the felony-murder rule cannot constitutionally apply to the class of crimes for which it was enacted. Hence, the court should declare the rule void.

Tamu Sudduth*

* A.B. 1974, University of California, Berkeley; M.A. 1977, Pepperdine University; thirdyear student, Boalt Hall School of Law, University of California, Berkeley. 